\title{
Use of nattokinase, a subtilisin-like serine proteinase, to accelerate proteolysis in Cheddar cheese during ripening
}

\author{
Vivek K. UPADHYAY, Alan L. KELLY, Paul L.H. MCSWEENEY* \\ Department of Food and Nutritional Sciences, University College, Cork, Ireland
}

Received 16 March 2005 - Accepted 2 March 2006

\begin{abstract}
Nattokinase, a subtilisin-like serine proteinase produced by Bacillus natto, is present in the traditional fermented Japanese soyabean product "natto". The aim of this study was to investigate the effects of a semi-purified preparation of nattokinase (added to cheesemilk at 80, 160 or $320 \mu \mathrm{g} \cdot \mathrm{mL}^{-1}$ ), on proteolysis in Cheddar cheese during cheese ripening. Levels of $\mathrm{pH} 4.6$-soluble $\mathrm{N}$ increased with ripening time and with level of addition of nattokinase. Specifically, increased breakdown of $\alpha_{\mathrm{s} 1}$ - and $\beta$-caseins was observed in experimental cheeses compared to control cheese. With increasing level of addition of nattokinase, increased production of a peptide with an electrophoretic mobility lower than that of the $\gamma$-caseins was observed. Principal component analysis of reversed-phase HPLC chromatograms of 70\% (v/v) ethanol-soluble fractions of cheeses clearly differentiated cheeses based on level of addition of nattokinase. Levels of most of the free amino acids were higher in experimental cheeses compared to the control; however, the increase was not proportional to level of addition of nattokinase. Overall, use of nattokinase as an exogenous enzyme accelerated primary proteolysis in Cheddar cheese and increased the pool of most of the free amino acids, which serve as substrates for many catabolic reactions and in turn affects the flavour of cheese.
\end{abstract}

\section{Cheddar cheese / nattokinase / proteolysis / accelerated ripening}

摘要 - 利用纳豆激酶促进切达干酪成熟过程中蛋白质水解的研究。纳豆激酶是由纳豆杆 菌 (Bacillus natto) 产生的类枯草杆菌蛋白酶的丝氨酸蛋白酶, 存在于日本传统发酵豆制品纳 豆中。本研究目的是探讨部分纯化的纳豆激酶对切达干酪成熟过程中蛋白质的水解作用, 纳豆激酶在原料乳中的添加量分别为 $80 、 160$ 和 $320 \mu \mathrm{g} \cdot \mathrm{mL}^{-1}$ 。随着成熟时间和纳豆激酶添 加量的增加, $\mathrm{pH} 4.6$ 可溶性氮的浓度相应地增加。与对照样品 (未添加纳豆激酶) 相比, 试验样品中 $\alpha_{\mathrm{s} 1}$ - 酪蛋白和 $\beta$ - 酪蛋白的降解量明显地增加。经电泳分析表明随着纳豆激酶 添加量的增加, 干酪成熟过程中肽的含量增加。采用高效液相色谱法分析了干酪的 $70 \%$ 乙 醇提取液中的可溶性成分, 在不同纳豆激酶添加量的干酪中一些主要成分含量之间存在着 明显的区别。与对照样品相比, 试验样品中游离氨基酸的浓度㫜显提高, 但是游离氨基酸 浓度的增加量与纳豆激酶的添加量并不是成比例的增加。因此, 纳豆激酶作为一种外源性 蛋白酶对促进切达干酪成熟过程蛋白质的水解, 增加游离氨基酸的蓄积, 对后期风味的形 成和改善等具有非常重要的作用。

切达干酪 / 纳豆激酶 / 蛋白质水解 / 促进作用

\footnotetext{
* Corresponding author (通讯作者): p.mcsweeney@ucc.ie
} 
Résumé - Utilisation de la nattokinase, une sérine protéase semblable à la substilisine, en vue d'accélérer la protéolyse du cheddar au cours de l'affinage. La nattokinase, une sérine protéase semblable à la substilisine produite par Bacillus natto, est présente dans le natto, produit fermenté traditionnel japonais à base de soja. Le but de cette étude était d'étudier les effets d'une préparation semi-purifiée de nattokinase ajoutée au lait de fabrication à raison de $80,160 \mathrm{ou} 320 \mu \mathrm{g} \cdot \mathrm{mL}^{-1}$ sur la protéolyse du cheddar au cours de l'affinage. Les niveaux d'azote soluble à pH 4,6 augmentaient avec le temps d'affinage et avec le niveau de nattokinase ajouté. Plus spécifiquement, une hydrolyse accrue des caséines $\alpha_{\mathrm{s} 1}$ et $\beta$ était observée dans les fromages expérimentaux. Lorsque les niveaux d'addition de nattokinase augmentaient, on observait une production accrue de peptides à mobilité électrophorétique inférieure à celle des caséines $\gamma$. L'analyse en composante principale des chromatogrammes RP-HPLC des fractions de fromage solubles dans l'éthanol à $70 \%$ (v/v) différenciait clairement les fromages selon le niveau de nattokinase. Les niveaux de la plupart des acides aminés libres étaient supérieurs dans les fromages expérimentaux par rapport au contrôle, cependant l'augmentation n'était pas proportionnelle au taux d'addition de nattokinase. Globalement, l'utilisation de nattokinase comme enzyme exogène accélérait la protéolyse primaire dans le cheddar et augmentait la présence de la plupart des acides aminés libres servant de substrat à plusieurs réactions catalytiques, ce qui en retour peut affecter la flaveur du fromage.

cheddar / nattokinase / protéolyse / affinage accéléré

\section{INTRODUCTION}

Cheese is a biochemically dynamic product that undergoes numerous changes after manufacture. Fresh cheese curd is bland in flavour, but during ripening, a series of complex biochemical changes takes place, resulting in development of the taste, aroma and texture, which are typical of the particular cheese variety [12-14, 16, $36]$. Of these biochemical changes, proteolysis is of most significance to hard cheese varieties such as Cheddar [29]. Agents of primary proteolysis (i.e., chymosin and plasmin) hydrolyse intact caseins to generate large and intermediate-sized peptides, which are then converted to small peptides and free amino acids by proteinases and peptidases of starter and non-starter lactic acid bacteria. Free amino acids act as substrates for secondary catabolic reactions, which are of great importance in production of various sapid compounds [23].

Cheese ripening is a slow process; hence, considerable financial investment is required to meet inventory costs, for storage space and for maintaining ripening rooms at defined ripening temperatures and relative humidities. It is estimated that cheese ripening costs approximately $€ 500-800$ per tonne of cheese matured for nine months [35]. Over the years, acceleration of cheese ripening has received considerable atten- tion, see reviews by $[6,11,15,19,35,38]$ and different strategies have been employed to accelerate this process. Addition of exogenous enzymes or semi-purified protein preparations to cheesemilk have been used successfully to accelerate ripening in different cheese varieties $[3,8$, 20, 21, 34, 37, 39].

"Natto" is a Japanese fermented soyabean product known for imparting various health benefits [17] and traditionally has been used to treat heart and vascular diseases, to relieve fatigue, as an anti-beriberi agent [30] and to reduce blood pressure. Natto has a characteristic typical taste and flavour, which are produced by Sumi et al. Bacillus natto [30]. The presence of a strong fibrinolytic enzyme in natto which was named "nattokinase", was first reported by Sumi et al. [30]. Nattokinase is a subtilisin-like serine proteinase with 275 amino acid residues, a molecular mass of $\sim 28 \mathrm{~kg} \cdot \mathrm{mol}^{-1}$ and a pI of 8.7 [17]. Plasmin inhibitors such as $\varepsilon$-amino caproic acid and trans-4-amino-methyl-cyclohexanecarboxylic acid do not inhibit the fibrinolytic activity of nattokinase. Moreover, the action of protease inhibitors such as phenylmethylsulfonyl fluoride and $N$-tocyl-Lphenylalanine chloromethylketone has indicated that nattokinase is a subtilisinlike protease rather than a plasmin-like protease [17]. The complete amino acid sequence of nattokinase shows high homology with subtilisins and is identical to that 
of subtilisin E and subtilisin J. The enzyme has greater activity on a substrate for subtilisin (Suc-Ala-Ala-Pro-Phe-pNA) than on a substrate for plasmin (H-D-Val-Leu-LyspNA; 17). Oral administration of nattokinase has shown an extended enhancement of fibrinolytic activity in the plasma [31].

The aim of this work was to use a semipurified preparation of nattokinase in the manufacture of Cheddar cheese to accelerate proteolysis as evaluated using chromatographic and electrophoretic techniques in combination with multivariate statistical analysis.

\section{MATERIALS AND METHODS}

\subsection{Cheese manufacture}

A semi-purified preparation of nattokinase was obtained from Coex Mart, World Trade Center, Seoul, South Korea. Pasteurised $\left(72{ }^{\circ} \mathrm{C}\right.$ for $\left.15 \mathrm{~s}\right)$ and standardised $(0.7: 1$ casein: fat ratio) milk for cheese manufacture was obtained from the Dairy Products Research Centre Moorepark, Fermoy, Co. Cork. Based on preliminary trials on cheese slurries, nattokinase was added to the cheesemilk at levels of 80,160 or $320 \mu \mathrm{g} \cdot \mathrm{mL}^{-1}$; cheese made from milk without addition of nattokinase acted as the control. Four batches of Cheddar cheese (one control and three experimental) were manufactured from 100 L of milk on three occasions (Trials A, B and C) by a conventional cheesemaking procedure, using Lc. lactis ssp. lactis 317 (Microbiology Department, University College, Cork) as starter and Maxiren 180 (DSM Food Specialties, Delft, The Netherlands) as coagulant. The cheeses were pressed overnight, vacuum packed and ripened at $9{ }^{\circ} \mathrm{C}$; samples were subsequently taken from the cheeses after 1 , 67,120 and $180 \mathrm{~d}$ of ripening. The cheese samples were grated immediately after sampling and stored at $-20{ }^{\circ} \mathrm{C}$ until analysed.

\subsection{Compositional analysis}

Cheddar-type cheeses were analysed for moisture [2] and protein (macro-Kjeldahl).
Salt in cheese was determined by a potentiometric method [10] and the $\mathrm{pH}$ of a cheese: water slurry (1:2) was measured. All compositional analyses were performed in triplicate. Analysis of variance was checked using SPSS statistical package (SPSS for Windows, Version 11.0, SPSS Inc, Chicago, USA) with Tukey's pairwise comparisons at the $95 \%$ confidence level.

\subsection{Assessment of proteolysis}

$\mathrm{pH}$ 4.6-soluble and -insoluble extracts were prepared from the cheeses by modification of procedure of [18], as described by [28]; the nitrogen content of these extracts was determined by the macro-Kjeldahl method and results were expressed as a percentage of total cheese nitrogen. The $\mathrm{pH}$ 4.6-insoluble fractions were lyophilised, while the $\mathrm{pH}$ 4.6-soluble fractions were sub-fractionated using $70 \%(\mathrm{v} / \mathrm{v})$ ethanol [28]; both the ethanol-soluble and -insoluble sub-fractions were lyophilised. Lyophilised $\mathrm{pH}$ 4.6-insoluble fractions were analysed by urea-polyacrylamide gel electrophoresis (PAGE) (12.5\% T, 4\% C, pH 8.9) according to the method of [1], as modified by [27]. Gels were stained [5], destained in distilled water and scanned on a flatbed scanner (HP Scanjet 6300C, Singapore) and densitometric analysis was performed on the scanned image using gel analysis software (Total Lab 1D, Nonlinear Dynamix, Newcastleupon-Tyne, United Kingdom). Peak volumes of individual bands, obtained by densitometric analysis of gels, were used as variables for principal component analysis (PCA), performed using a covariance matrix by the SPSS statistical package (SPSS for Windows, Version 11.0, SPSS Inc., USA). Groupings on the score plots were obtained by performing hierarchical cluster analysis on the data.

Peptide profiles of $70 \%$ ethanol-soluble fractions were determined [28] and data obtained were analysed by multivariate statistical techniques. The data for factor reduction analysis were obtained by taking peak heights as variables and pre-processed using a logistic function [24]; after this step, processed data consisted of classes of retention time (retention classes) wherein peak 
Table I. Compositions of Cheddar cheeses made from milk with different levels of added nattokinase.

\begin{tabular}{lccccc}
\hline \multirow{2}{*}{$\begin{array}{l}\text { Nattokinase level } \\
\left(\mu \mathrm{g} \cdot \mathrm{mL}^{-1}\right)\end{array}$} & $\mathrm{pH}$ & \multicolumn{5}{c}{$\%$} \\
\cline { 3 - 6 } & & Moisture & Protein & Salt & $\mathrm{S} / \mathrm{M}^{*}$ \\
\hline 0 & $5.10(0.04)$ & $39.60(1.24)$ & $26.04(0.80)$ & $1.06(0.11)$ & $2.60(0.27)$ \\
80 & $5.04(0.04)$ & $39.28(1.29)$ & $25.72(0.65)$ & $1.11(0.09)$ & $2.71(0.22)$ \\
160 & $5.00(0.03)$ & $38.74(0.53)$ & $25.72(0.20)$ & $1.13(0.10)$ & $2.76(0.24)$ \\
320 & $5.03(0.04)$ & $39.42(1.05)$ & $25.69(0.76)$ & $1.21(0.12)$ & $2.95(0.29)$ \\
\hline
\end{tabular}

* Salt-in-moisture.

Values in parenthesis indicates \pm SD of three trials.

heights were accumulated using the distance from centre of class as a weight. Factor reduction analysis was performed on the processed data using the covariance matrix for determination of principal components [25] using the SPSS statistical package. Analysis of individual free amino acids was performed using the method described by [9] on $12 \%$ trichloroacetic acid (TCA) soluble sub-fractions of the $\mathrm{pH}$ 4.6-soluble extracts prepared after $180 \mathrm{~d}$ of cheese ripening. The TCA soluble sub-fractions were diluted with $0.2 \mathrm{M}$ sodium citrate buffer $(\mathrm{pH} 2.2)$ to give approximately $250 \mathrm{nmol}$ of each amino acid residue. The samples were diluted 1:2 with norleucine, the internal standard, to give approximately $125 \mathrm{nmol}$ of each amino acid residue/ml of injection volume. Samples were then analysed on a $120 \times 4 \mathrm{~mm}$ cation-exchange column $\left(\mathrm{Na}^{+}\right.$ form) with a Beckman 6300 High Performance Amino Acid Analyser (Beckman Instruments Ltd, High Wycombe, UK). The individual amino acids were separated by ion-exchange chromatography with postcolumn ninhydrin derivatization and visible colorimetric detection. The amino acids were detected at $570 \mathrm{~nm}$ with the exception of proline, which was detected at $400 \mathrm{~nm}$. Results were recorded using a Minichrom data handling system (VG DataSystems, Altrincham, Cheshire, UK).

\subsection{Plasmin assay}

The cheeses were assayed for plasmin activity and plasminogen levels by a modification of the method of Richardson and
Pearce [26]. Grated cheese (3 g) was mixed with $2 \%(\mathrm{w} / \mathrm{v})$ trisodium citrate $(27 \mathrm{~mL})$ and stomached for $5 \mathrm{~min}$ in a laboratory stomacher (Colworth Stomacher 400, Seward Laboratory, London, UK). The resultant homogenate was equilibrated at $37^{\circ} \mathrm{C}$ for $15 \mathrm{~min}$ before centrifuging at $27000 \times g$ for $30 \mathrm{~min}$ at $4{ }^{\circ} \mathrm{C}$. The supernatant beneath the fat layer was assayed for plasmin activity using $N$-succinyl-alanyl-phenylalanyl-lysyl-7-amido-4-methyl-coumarin (Suc-Ala-Phe-Lys-AMC) as substrate. Plasminogen-derived activity in the supernatant was determined after activating plasminogen to plasmin using $0.2 \mathrm{U} \cdot \mathrm{mL}^{-1}$ urokinase (Fluka Laboratories, Buchs, Switzerland). Plasmin activity in cheese was expressed as plasmin units $\mathrm{g}^{-1}$ cheese (where 1 unit was defined as the activity necessary to release $1 \mathrm{nmol}$ of 7-amido-4methyl-coumarin from Suc-Ala-Phe-Lys$\mathrm{AMC}$ per min at $\mathrm{pH} 7.5$ and $25^{\circ} \mathrm{C}$ ).

\section{RESULTS AND DISCUSSION}

Composition and $\mathrm{pH}$ of Cheddar cheeses manufactured from milk with different levels of nattokinase (experimental) or without addition of nattokinase (control) were analysed $1 \mathrm{~d}$ after manufacture (Tab. I). Values for $\mathrm{pH}$, moisture and protein content were similar in control and experimental cheeses. Similar values for $\mathrm{pH}$, moisture and protein for Cheddar cheese made in a pilot scale have been reported [3, 37]. Salt content and salt-in-moisture levels were low compared to normal values for Cheddar cheese 


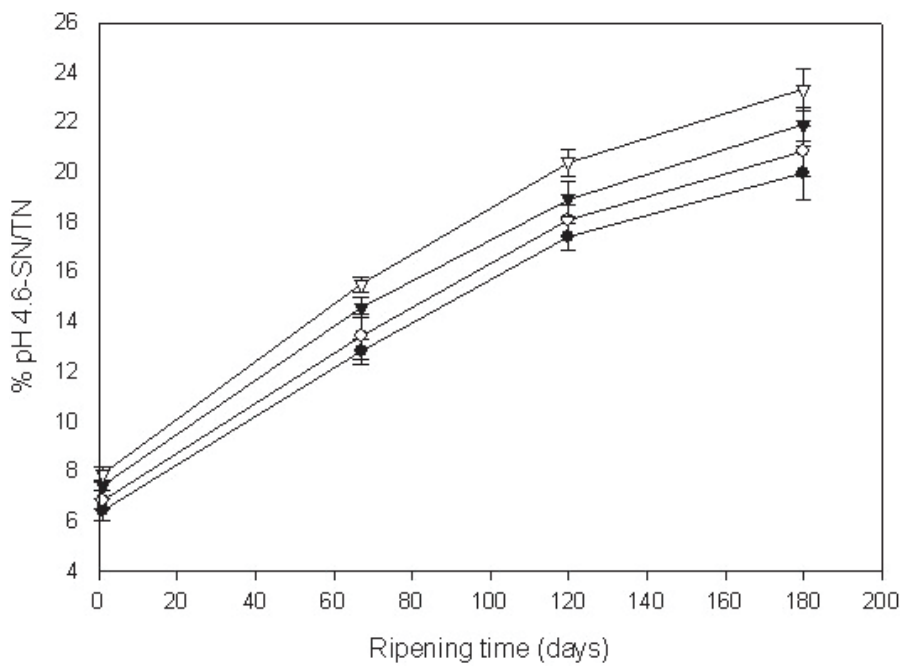

Figure 1. Changes in $\mathrm{pH} 4.6-\mathrm{SN}$ as $\%$ of TN, during ripening of Cheddar cheese made from milk supplemented with $0(\bullet), 80(\mathrm{O}), 160(\boldsymbol{\nabla})$ or $320(\nabla) \mu \mathrm{g} \cdot \mathrm{mL}^{-1}$ nattokinase. Values are means \pm standard deviations of data from triplicate analyses of cheeses from 3 separate trials.

$(\sim 1.5$ and $\sim 5.0 \%$, respectively); however, no differences were apparent between control and experimental cheeses. Overall results in Table I indicate that addition of nattokinase at different levels in cheesemilk for manufacture of Cheddar cheese did not result in compositional differences.

Primary proteolysis was measured in control and experimental Cheddar cheeses by measuring the levels of $\mathrm{pH} 4.6$-soluble nitrogen $(\mathrm{SN})$ calculated as \% of total nitrogen (TN) (pH 4.6-SN/TN) at various ripening times (Fig. 1). Levels of $\mathrm{pH} 4.6 \mathrm{SN} / \mathrm{TN}$ ranged from $6.47 \%$ (control) to 7.91 (cheese made from milk with $320 \mu \mathrm{g} \cdot \mathrm{mL}^{-1}$ nattokinase) after day 1 and $19.97 \%$ (control) to $23.32 \%$ (320 $\mu \mathrm{g} \cdot \mathrm{mL}^{-1}$ nattokinase) after $180 \mathrm{~d}$ of ripening. The milk coagulating enzyme, chymosin and the indigenous milk proteinase, plasmin, are the principal agents responsible for primary proteolytic agent in Cheddar cheese. Action of these proteolytic agents on the caseins results in the formation of large and intermediatesized peptides, some of which are soluble in water [36].
In the control cheese, levels of $\mathrm{pH}$ 4.6SN/TN increased as ripening progressed, probably due to the action of chymosin and plasmin, whereas in cheeses manufactured from milk supplemented with different amounts of nattokinase, levels of $\mathrm{pH}$ 4.6$\mathrm{SN} / \mathrm{TN}$ increased in a manner proportional to the amount of nattokinase added. In control and experimental cheeses, increases in levels of $\mathrm{pH}$ 4.6-SN/TN followed a curvilinear pattern. This trend in the production of $\mathrm{SN}$ during ripening can be attributed to availability of cleavage sites for the primary proteolytic agents.

At the beginning of ripening, these sites are readily available for hydrolysis by chymosin or plasmin (or nattokinase in experimental cheese), hence generating soluble peptides at a constant rate; however, with the ongoing progress of ripening, more casein has been hydrolysed and the availability of such sites becomes limiting, thus reducing the rate of formation of $\mathrm{pH}$ 4.6SN. Differences in the levels of $\mathrm{pH}$ 4.6-SN between control and experimental cheeses were apparent from day 1 of ripening (Fig. 1) 


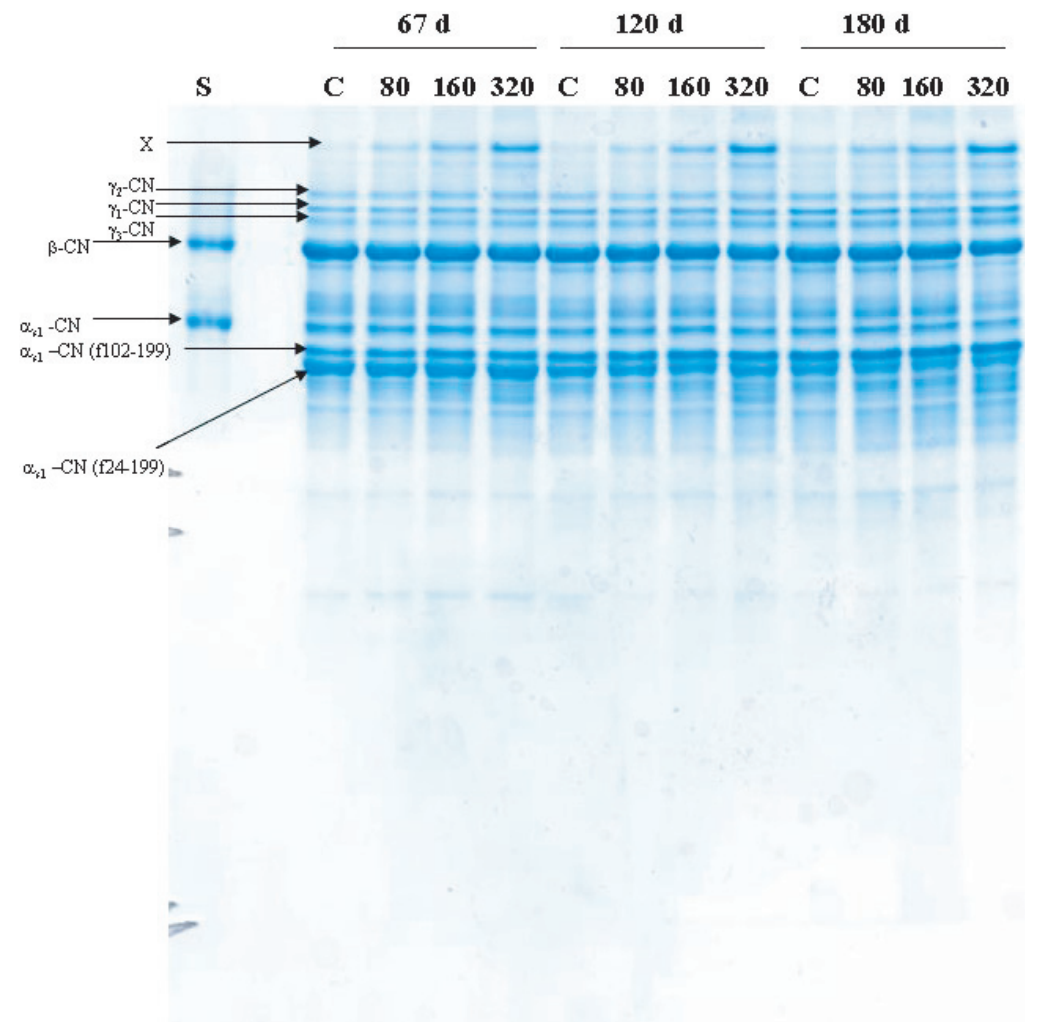

Figure 2. Urea-polyacrylamide gel electrophoretograms of $\mathrm{pH}$ 4.6-insoluble fractions of Cheddar cheese of a single trial made from milk supplemented with $0,80,160$ or $320 \mu \mathrm{g} \cdot \mathrm{mL}^{-1}$ nattokinase at 67,120 or $180 \mathrm{~d}$ of ripening.

and these differences increased in magnitude with the progress of ripening. At the end of ripening, $\mathrm{pH}$ 4.6-SN content of experimental Cheddar cheese increased by $4.5,10$ or $17 \%$ compared to the control when cheesemilk was supplemented with 80 , 160 or $320 \mu \mathrm{g} \cdot \mathrm{mL}^{-1}$ nattokinase, respectively. Law and Wigmore [20] and Farkye and Fox [7] achieved a $20 \%$ increase in SN content using Neutrase, a neutral proteinase produced by Bacillus subtilis, and exogenous plasmin, respectively, for the manufacture of Cheddar cheese.

Analysis of $\mathrm{pH}$ 4.6-insoluble fractions of control and experimental Cheddar cheeses by urea-PAGE showed the qualitative pattern of proteolysis during ripening (Fig. 2). The principal caseins, $\alpha_{\mathrm{s} 1}$-casein and $\beta$-casein, which are the preferred substrates for chymosin and plasmin, respectively, were degraded gradually during ripening. Hydrolysis of $\alpha_{\mathrm{s}_{1} \text {-casein by chymosin }}$ resulted in $\alpha_{\mathrm{s} 1}-\mathrm{CN}$ (f24-199), which was subsequently hydrolysed to $\alpha_{\mathrm{s} 1}-\mathrm{CN}$ (f102199 ) by chymosin, while hydrolysis of $\beta$-casein by plasmin resulted in formation of $\gamma_{1^{-}}, \gamma_{2^{-}}$and $\gamma_{3^{-}} \mathrm{CN}$ (Fig. 2). With progressing ripening, intensity of these breakdown products from $\alpha_{\mathrm{s} 1}$ - and $\beta$-caseins increased in control and experimental cheeses; however, the rate of their production differed. As level of addition of nattokinase to milk increased, increased production of peptide, of electrophoretic mobility lower than $\gamma$-caseins (marked $\mathrm{X}$ on Fig. 2) was observed. 
Levels of peptide $\mathrm{X}$ increased in control and experimental cheeses as ripening progressed; however, the level was maximum at highest levels of addition of nattokinase $\left(320 \mu \mathrm{g} \cdot \mathrm{mL}^{-1}\right)$, suggesting that peptide $\mathrm{X}$ was produced by the action of nattokinase. Accelerated breakdown of caseins has been observed in other studies where cheesemilk was supplemented with exogenous proteinases or plasminogen activators [3, 20, 37].

Densitometric analysis of urea-PAGE gels was performed to confirm visual observations (Fig. 3a) and peak volumes of electrophoretic bands were measured. During ripening, the peak volumes of bands corresponding to $\alpha_{\mathrm{s} 1}$ - and $\beta$-caseins decreased in control and experimental cheese; however, experimental cheese showed greater decreases in peak volumes of $\alpha_{s 1}$-and $\beta$-caseins, compared to control (not shown). The data for peak volumes of the bands separated by urea-PAGE were analysed by performing multivariate statistical techniques (Fig. 3b,c). PCA explained $96.9 \%$ of the variation between the samples on two principal components (PC) 1 and PC2, which accounted for $66.5 \%$ and $30.4 \%$ of variation, respectively. PC1 separated samples based on combination of age of cheese $(67,120$ or $180 \mathrm{~d}$ ) and treatment, while PC2 separated samples based on treatment (Fig. 3c).

Experimental cheese manufactured with the highest level of added nattokinase $\left(320 \mu \mathrm{g} \cdot \mathrm{mL}^{-1}\right)$ was different to the control cheese after $67 \mathrm{~d}$ of ripening on $\mathrm{PC} 1$, while differences between control cheese and cheese manufactured with lower levels of nattokinase $\left(80 \mu \mathrm{g} \cdot \mathrm{mL}^{-1}\right.$ or $\left.160 \mu \mathrm{g} \cdot \mathrm{mL}^{-1}\right)$ became apparent on $\mathrm{PC} 1$ as ripening progressed.

Factor loadings for PC1 had negative values for $\alpha_{s 1^{-}}, \beta$ - and $\alpha_{s 1}-\mathrm{CN}$ (f24-199) and positive values for $\alpha_{\mathrm{s} 1}-\mathrm{CN}$ (f102-199), $\gamma_{1}$ - and $\gamma_{3}$-CN (Fig. 3b). Accumulation of $\alpha_{\mathrm{s} 1}-\mathrm{CN}$ (f102-199) and $\gamma_{1^{-}}$and $\gamma_{3}$-caseins, explained most of the variation on PC1. Variation on PC2 was due to positive factor loadings for peptide $X$ and $\gamma_{2}$-casein and negative values for $\alpha_{s 1^{-}}, \beta$-casein (Fig. 3b). Factor loadings for peptide $X$ and $\beta$-casein on PC2 were of opposite magnitude, indicating accelerated breakdown of $\beta$-casein and accumulation of peptide X. HCA clus- tered cheeses into four main subgroups (not shown).

The first subgroup included control and experimental cheeses at $67 \mathrm{~d}$. In this subgroup, control and experimental cheeses (made from milk supplemented with 80 or $160 \mu \mathrm{g} \cdot \mathrm{mL}^{-1}$ nattokinase) grouped closely, while cheese manufactured using the highest levels of nattokinase $\left(320 \mu \mathrm{g} \cdot \mathrm{mL}^{-1}\right)$ grouped separately from the remaining cheeses. The second and third subgroup included control and experimental cheeses made from milk supplemented with 80 or $160 \mu \mathrm{g} \cdot \mathrm{mL}^{-1}$ nattokinase at 120 and $180 \mathrm{~d}$, respectively, while the fourth subgroup clustered cheeses manufactured from highest levels of nattokinase at 120 and $180 \mathrm{~d}$. Breakdown patterns of $\alpha_{\mathrm{s} 1^{-}}$and $\beta$-casein between control and cheese manufactured from highest levels of added nattokinase $\left(320 \mu \mathrm{g} \cdot \mathrm{mL}^{-1}\right)$ were different after $67 \mathrm{~d}$ of ripening (Cluster 1), which became very distinct as ripening progressed.

At the levels at which nattokinase was added to cheesemilk (80, 160 or $320 \mu \mathrm{g} \cdot \mathrm{mL}^{-1}$ ), it did not show activity on the substrate used to assay for plasmin activity. Plasmin activity in control and experimental cheeses did not differ at the end of ripening (data not shown); moreover, results of urea-PAGE showed little difference in levels of $\gamma$-caseins, which are the breakdown products of plasmin action on $\beta$-casein [4] between control and experimental cheeses made from milk supplemented with nattokinase. These results indicate little or no activation of plasminogen to plasmin by nattokinase in the complex environment of cheese, although a strong pro-urokinase activator activity in natto has been previously attributed to nattokinase [32, 33].

Reversed-phase HPLC provides valuable information about changes in levels and profiles of intermediate to small-sized peptides in cheese during ripening [22]. Typical RPHPLC chromatograms of lyophilised $70 \%$ ethanol-soluble fractions for control and experimental (made from milk supplemented with $320 \mu \mathrm{g} \cdot \mathrm{mL}^{-1}$ nattokinase) cheeses are shown in Figure 4a. Quantitative differences in cumulative peak heights in different retention classes in chromatograms of control and experimental cheeses were 

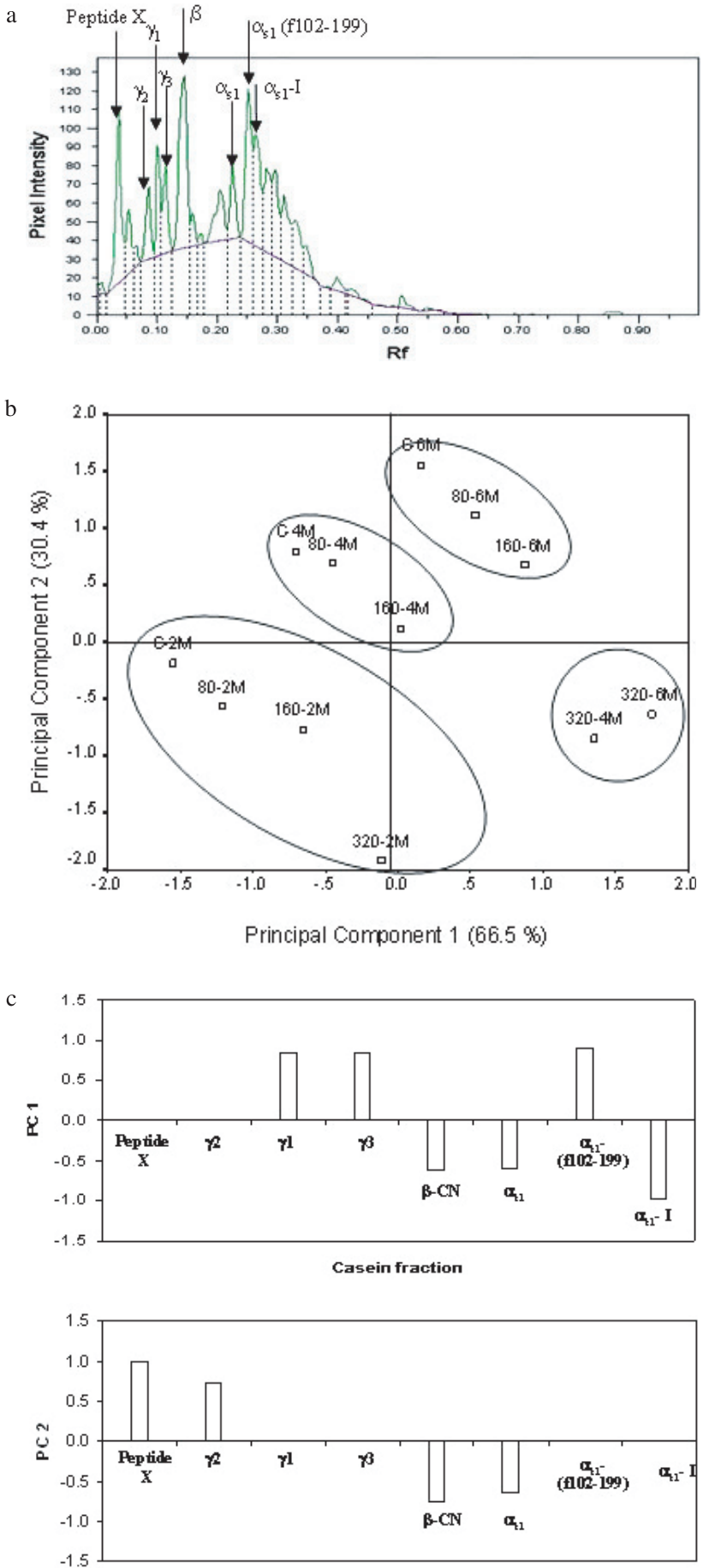
observed (Fig. 4b,c). PCA of cumulative peak heights at different retention classes of different samples explained $76.6 \%$ of total variation by two PCs (PC1 and PC2 explained $56.7 \%$ and $19.9 \%$ of variation, respectively) (Fig. 4d).

At the beginning of ripening, the samples were grouped closely on PC1, but as the ripening progressed, experimental cheeses separated from the control. Later in the ripening, cheeses manufactured from milk with 160 and $320 \mu \mathrm{g} \cdot \mathrm{mL}^{-1}$ added nattokinase separated distinctly on PC1 from rest of the samples (Fig. 4d). Plotting factor loadings for PC1 and PC2 against retention classes differentiated factor loadings responsible for the variation on respective PCs (Fig. 4b,c). Separation of samples on PC1 reflected formation and degradation of some peptides during cheese ripening due to the action of nattokinase. Moreover, retention classes with factor loadings that were responsible for the variation on PC1 corresponded to more hydrophobic peptides (peptides eluting in the region of 30 and $60 \mathrm{~min}$ ).

Nattokinase is a subtilisin-like serine proteinase and subtilisins or neutral proteinases have a tendency to produce hydrophobic peptides [20]; addition of nattokinase to cheesemilk clearly increased production of hydrophobic peptides, resulting in variation between samples on PC1. Factor loadings for PC2 showed that peptides with short elution times, which are hydrophilic in nature, were largely responsible for the variation on this component.

Analysis of individual and total free amino acids indicated differences between control and experimental cheeses (Fig. 5). Levels of many amino acids were higher in cheeses supplemented with nattokinase compared to the control; however, the increase in free amino acids in experimental cheese was not proportional to the rate of addition of nattokinase to cheesemilk. At the end of ripening, glutamic acid, phenylalanine, lysine, leucine and valine were found to be dominant in 12\% TCA-soluble fraction of Cheddar cheese. The same amino acids have been found to be dominant in Cheddar cheese $[3,39]$. Results of urea-PAGE (Fig. 2) showed accelerated breakdown of caseins by nattokinase to large and intermediate-sized peptides. These peptides, which are subsequently degraded to small peptides by various peptidases or proteinases in cheese, are precursors for the production of free amino acids. Use of nattokinase may increase the substrate pool for production of amino acids; however, in the absence of increased peptidase activity, the increase in amino acids level was not proportional to the rate of addition of nattokinase.

\section{CONCLUSION}

Use of a semi-purified preparation of exogenous nattokinase for the manufacture of Cheddar cheese accelerated production of $\mathrm{pH} 4.6-\mathrm{SN}$ by $\sim 17 \%$ compared to control. Use of this subtilisin-like serine proteinase enhanced breakdown of $\alpha_{\mathrm{s} 1^{-}}$and $\beta$-casein. Little or no difference was observed in the plasmin activity between control and experimental cheese, indicating little or no activation of plasminogen by nattokinase in cheese. Reversed-phase HPLC chromatograms showed increased production of hydrophobic peptides in experimental cheese compared to the control. Levels of most of the individual free amino acids were higher in experimental cheeses compared to control cheeses; however, the increase was not proportional to level of addition of nattokinase.

Figure 3. (a) Typical densitometric profile of the urea-polyacrylamide gel electrophoretogram of $180 \mathrm{~d}$ old Cheddar cheese, (b) score plot obtained by principal component analysis (PCA) of densitometric data from urea-polyacrylamide gel electrophoresis of Cheddar cheeses of a single trial made from milk supplemented with 0 (C), 80,160 or $320 \mu \mathrm{g} \cdot \mathrm{mL}^{-1}$ nattokinase after $67(2 \mathrm{M})$; $120(4 \mathrm{M})$ or $180(6 \mathrm{M}) \mathrm{d}$ of ripening, and (c) factor loadings for principal components 1 and 2 obtained by principal component analysis of densitometric data. 
(a)
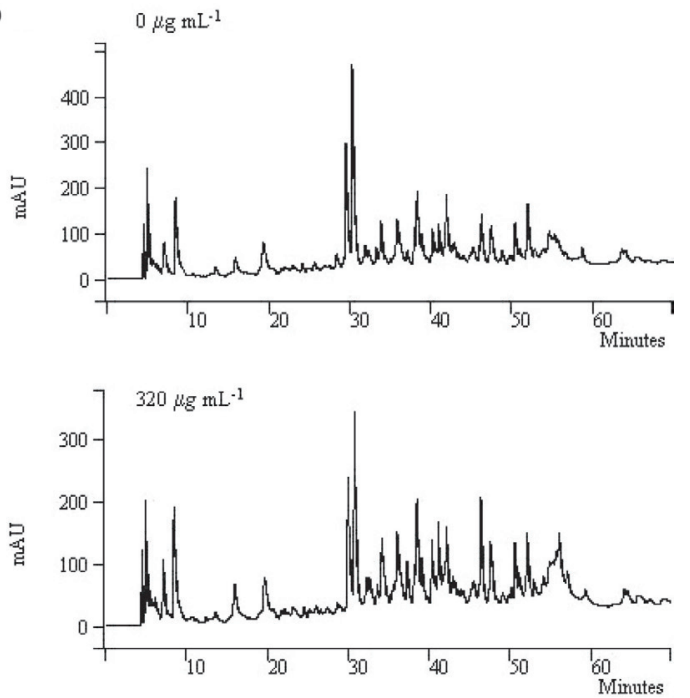

(b)
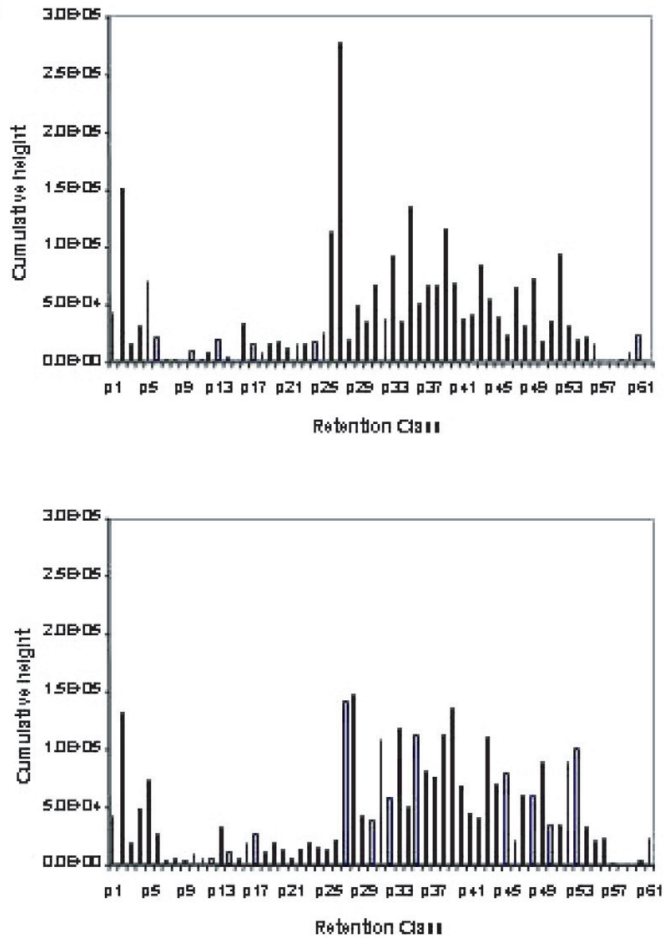

Figure 4. (a) Reversed-phase HPLC chromatograms of $70 \%$ (v/v) ethanol-soluble sub-fractions of $\mathrm{pH}$ 4.6-soluble extracts of Cheddar cheese (Trial A) made from milk supplemented with 0 or $320 \mu \mathrm{g} \cdot \mathrm{mL}^{-1}$ nattokinase at $180 \mathrm{~d}$ of ripening, (b) cumulative heights at different retention classes for chromatographic data from Cheddar cheese made from milk supplemented with $0 \mathrm{or} 320 \mu \mathrm{g} \cdot \mathrm{mL}^{-1}$ nattokinase at $180 \mathrm{~d}$ of ripening. 
(c)
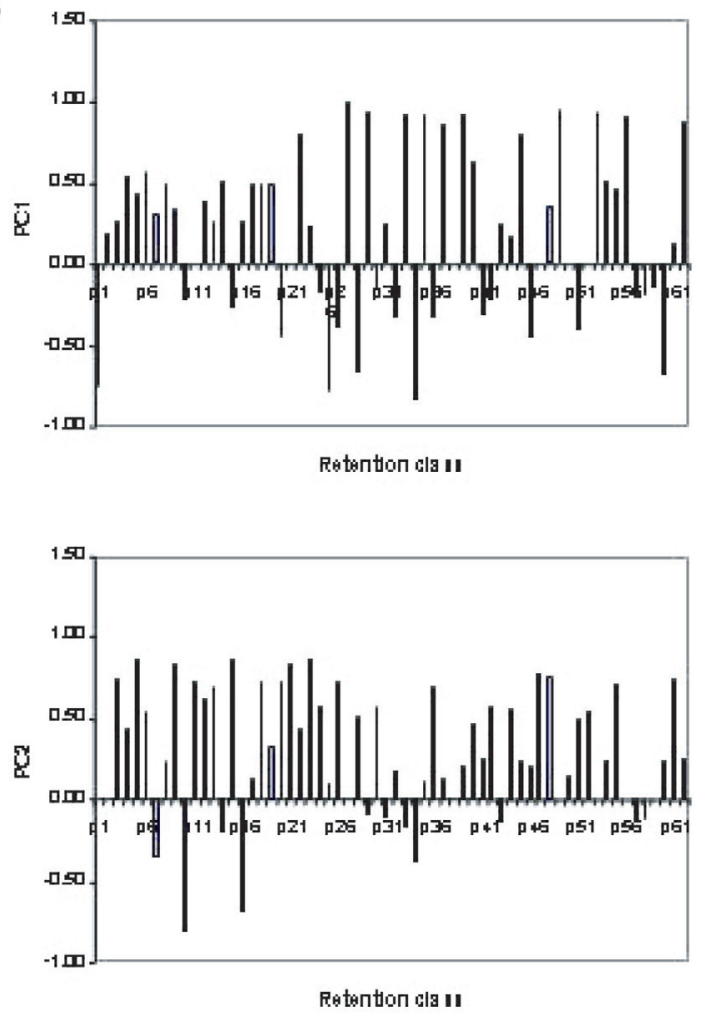

(d)

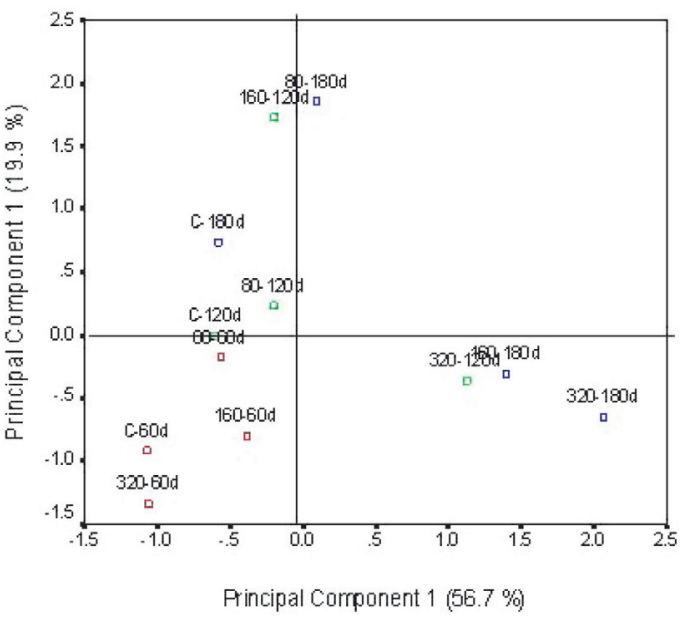

Figure 4. (c) Factor loadings for principal components 1 and 2 obtained by principal component analysis (PCA) of cumulative heights at different retention classes and (d) score plot obtained by PCA of data from reversed-phase HPLC chromatograms of 70\% (v/v) ethanol-soluble fractions from Cheddar cheese made from milk supplemented with $0,80,160$ or $320 \mu \mathrm{g} \cdot \mathrm{mL}^{-1}$ nattokinase after 67,120 or $180 \mathrm{~d}$ of ripening. 


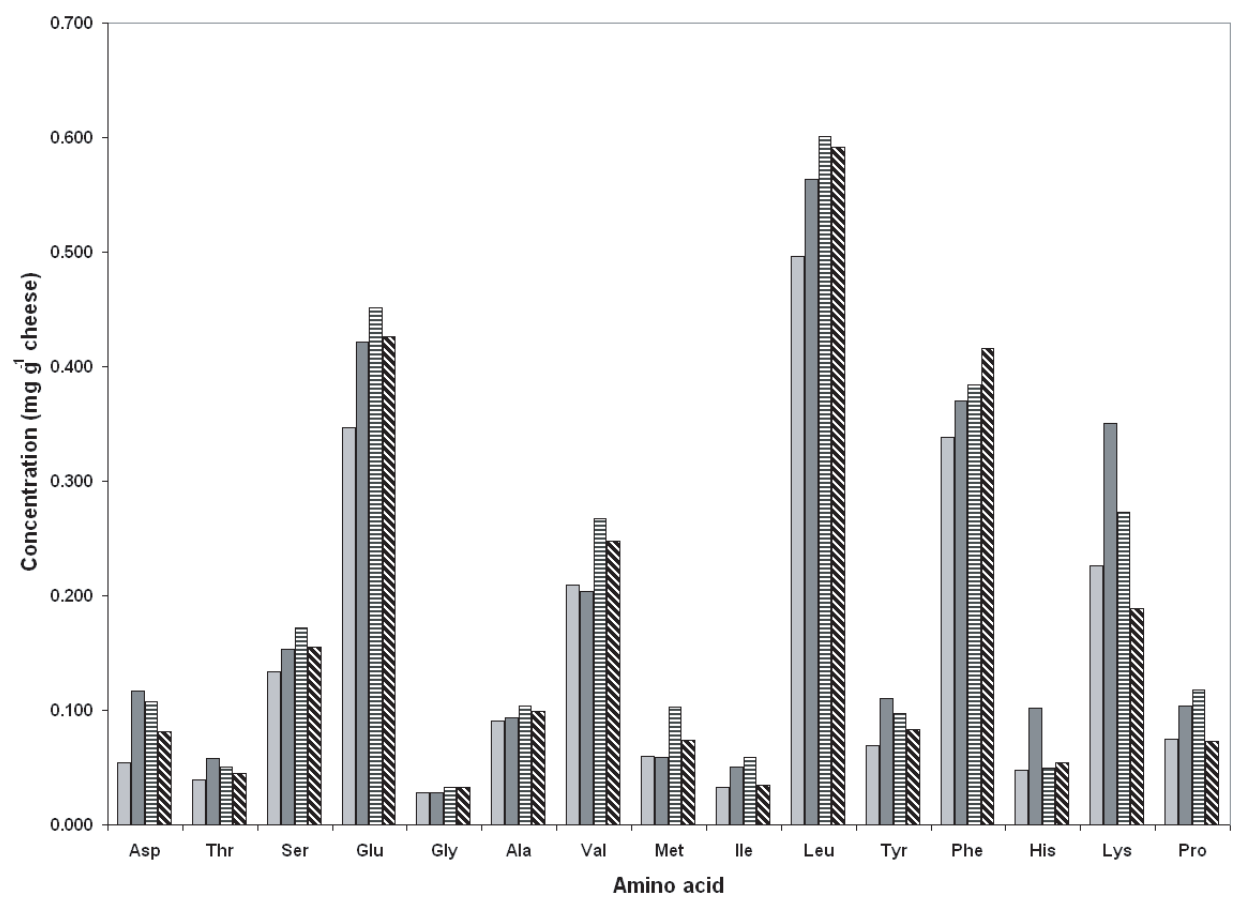

Figure 5. Levels of individual free amino acids in $\mathrm{pH}$ 4.6-soluble fractions of Cheddar cheese made from milk supplemented with $0(\square), 80(\square), 160\left(\right.$ 国) or $320(\mathbb{\mathbb { E }}) \mu \mathrm{g} \cdot \mathrm{mL}^{-1}$ nattokinase after $180 \mathrm{~d}$ of ripening.

In conclusion, use of nattokinase for Cheddar cheese manufacture accelerated proteolysis during ripening and use of attenuated starters in combination with nattokinase may accelerate peptide breakdown and enhance breakdown of hydrophobic and potentially bitter peptides produced by nattokinase, which may aid in improvement of cheese flavour.

Acknowledgements: The authors wish to thank Mr. Dave Waldron (Department of Food and Nutritional Science, University College Cork) for his help with cheesemaking.

\section{REFERENCES}

[1] Andrews A.T., Proteinases in normal bovine milk and their action on caseins, J. Dairy Res. 50 (1983) 45-55.

[2] Ardö Y., Polychroniadou A., Laboratory Manual for Chemical Analysis of Cheese, Office for Official Publications of the European Communities, COST, Brussels, Belgium, 1998.

[3] Barrett F.M., Kelly A.L., McSweeney P.L.H., Fox P.F., Use of exogenous urokinase to accelerate proteolysis in Cheddar cheese during ripening, Int. Dairy J. 9 (1999) 421-427.

[4] Bastian E.D., Brown R.J., Plasmin in milk and dairy products, Int. Dairy J. 6 (1996) 435-457. 
[5] Blakesley R.W., Boezi J.A., A new staining technique for proteins in polyacrylamide gels using Coomassie Brilliant Blue G250, Anal. Biochem. 82 (1977) 580-588.

[6] El Soda M., Pandian S., Recent developments in accelerated cheese ripening, J. Dairy Sci. 74 (1991) 2317-2335.

[7] Farkye N.Y., Fox P.F., Contribution of plasmin to Cheddar cheese ripening: effect of added plasmin, J. Dairy Res. 59 (1992) 209216.

[8] Fedrick I.A., Cromie S.J., Dulley J.R., The effects of increased starter populations, added neutral proteinase and elevated temperature storage on Cheddar cheese manufacture and maturation, N.Z. J. Dairy Sci. Technol. 21 (1986) 191-203.

[9] Fenelon M.A., O'Connor P., Guinee T.P., The effect of fat content on the microbiology and proteolysis in Cheddar cheese during ripening, J. Dairy Sci. 83 (2000) 2173-2183.

[10] Fox P.F., Potentiometric determination of salt in cheese, J. Dairy Sci. 46 (1963) 744-745.

[11] Fox P.F., Acceleration of cheese ripening, Food Biotechnol. 2 (1988/89) 133-185.

[12] Fox P.F., Wallace J.M., Formation of flavour compounds, Adv. Appl. Microbiol. 45 (1997) 17-85.

[13] Fox P.F., Law J., McSweeney P.L.H., Wallace J., Biochemistry of cheese ripening, in: Fox P.F. (Ed.), Cheese: Chemistry, Physics and Microbiology, Vol. 1, General Aspects, 2nd edn., Chapman and Hall, London, England, 1993, pp. 389-438.

[14] Fox P.F., O'Connor T.P., McSweeney P.L.H., Guinee T.P., O'Brien N.M., Cheese: Physical, chemical, biochemical and nutritional aspects, Adv. Food Nutr. Res. (1996) 163-328.

[15] Fox P.F., Wallace J.M., Morgan S., Lynch C.M., Niland E.J., Tobin J., Acceleration of cheese ripening, Anton. Leeuwenhoek 70 (1996) 271-297.

[16] Fox P.F., Guinee T.P., Cogan T.M., McSweeney P.L.H., Fundamentals of Cheese Science, Aspen Publishers, Gaithersburg, MD, USA, 2000.

[17] Fujita M., Nomura K., Hong K., Ito Y., Asada A., Nishimuro S., Purification and characterization of a strong fibrinolytic enzyme (nattokinase) in the vegetable cheese natto, a popular soybean fermented food in Japan, Biochem. Biophys. Res. Comm. 197 (1993) 134-1347.

[18] Kuchroo C.N., Fox P.F., Soluble nitrogen in Cheddar cheese: comparison of extraction procedures, Milchwissenschaft 37 (1982) 331-335.
[19] Law B.A., Controlled and accelerated cheese ripening: the research base for new technologies, Int. Dairy J. 11 (2001) 383-398.

[20] Law B.A., Wigmore A.S., Accelerated ripening with food grade proteinases, J. Dairy Res. 49 (1982) 137-146.

[21] Law B.A., Wigmore A.S., Accelerated ripening of Cheddar cheese with a commercial proteinase and intracellular enzymes of starter streptococci, J. Dairy Res. 50 (1983) 519 525.

[22] McSweeney P.L.H., Fox P.F., Chemical methods for the characterization of proteolysis in cheese during ripening, Lait 77 (1997) 41-76.

[23] McSweeney P.L.H., Sousa M.J., Biochemical pathways for the production of flavour compounds in cheese during ripening, Lait 80 (2000) 293-324.

[24] Piraino P., Parente E., McSweeney P.L.H., A new approach for preprocessing of chromatographic data and chemometrical analysis of proteolytic profiles of cheese extracts, J. Agric. Food Chem. 52 (2004) 6904-6911.

[25] Pripp A.H., Shakeel-Ur-Rehman, McSweeney P.L.H., Fox P.F., Multivariate statistical analysis of peptide profiles and free amino acids to evaluate effects of single-strain starters on proteolysis in miniature Cheddar-type cheeses, Int. Dairy J. 9 (1999) 473-479.

[26] Richardson B.C., Pearce K.N., The determination of plasmin in dairy products, N.Z. J. Dairy Sci. Technol. 16 (1981) 209-220.

[27] Shalabi S.I., Fox P.F., Electrophoretic analysis of cheese, comparison of methods, Irish J. Food Sci. Technol. 11 (1987) 135-151.

[28] Sousa M.J., McSweeney P.L.H., Studies on the ripening of Cooleeney, an Irish farmhouse Camembert-type cheese, Irish J. Agric. Food Res. 40 (2001) 83-95.

[29] Sousa M.J., Ardö Y., McSweeney P.L.H., Advances in the study of proteolysis during cheese ripening, Int. Dairy J. 11 (2001) 327-345.

[30] Sumi H., Hamada H., Tsushima H., Mihara H., Muraki H., A novel fibrinolytic enzyme (nattokinase) in the vegetable cheese natto a typical and popular soybean food in the Japanese diet, Experientia 43 (1987) 11101111.

[31] Sumi H., Hamada H., Nakanishi K., Hiratani $\mathrm{H}$., Enhancement of the fibrinolytic-activity in plasma by oral-administration of nattokinase, Acta Haematologica 84 (1990) 139-143.

[32] Sumi H., Yatagai C., Kishimoto N., A very strong activity of pro-urokinase activator in 
natto, the traditional fermented soybean product in Japan, Fibrinolysis 10 (1996) 31.

[33] Sumi H., Tomohiro S., Yatagai C., Yasutaka $\mathrm{K}$., Determination and properties of the fibrinolysis accelerating substance (FAS) in Japanese fermented soybean "natto", Nippon Nogeikagaku Kaishi 74 (2000) 1259-1264.

[34] Trépanier G., Abboudi M., Lee B.H., Simard R.E., Accelerated maturation of Cheddar cheese: Influence of added lactobacilli and commercial protease on composition and texture, J. Food Sci. 57 (1992) 898-902.

[35] Upadhyay V.K., McSweeney P.L.H., Acceleration of cheese ripening, in: Smit G. (Ed.), Dairy Processing: Improving Quality, Woodhead Publishing, Cambridge, England, 2003, pp. 419-447.

[36] Upadhyay V.K., McSweeney P.L.H., Magboul A.A.A., Fox P.F., Proteolysis in cheese during ripening, in: Fox P.F., McSweeney P.L.H., Cogan T.M., Guinee T.P. (Eds.), Cheese: Chemistry, Physics and Microbiology, Vol. 1 General Aspects, 3rd edn., Elsevier, London, 2004, pp. 391-433.

[37] Upadhyay V.K., Sousa M.J., Ravn P., Israelsen H., Kelly A.L., McSweeney P.L.H., Use of exogenous streptokinase to accelerate proteolysis in Cheddar cheese, Lait 84 (2004) 527-538.

[38] Wilkinson M.G., Acceleration of cheese ripening, in: Fox P.F. (Ed.), Cheese: Chemistry, Physics and Microbiology, Vol. 1, General Aspects, 2nd edn., Chapman and Hall, London, 1993, pp. 523-555.

[39] Wilkinson M.G., Guinee T.P., O'Callaghan D.M., Fox P.F., Effects of commercial enzymes on proteolysis and ripening in Cheddar cheese, Lait 72 (1992) 449-459. 